\title{
Salivary Flow and ph in pregnant patients
}

\section{Flujo y ph salival en pacientes en pacientes gestantes}

\author{
CAPETILLO-HERNÁNDEZ, Guadalupe Rosalía†*, OCHOA-MARTÍNEZ, Rosa Elena, TORRES- \\ CAPETILLO, Evelyn Guadalupe and TIBURCIO-MORTEO, Leticia
}

Universidad Veracruzana, Facultad de Odontología, Región Veracruz, México

ID $1^{\text {st }}$ Author: Guadalupe Rosalía, Capetillo-Hernández / ORC ID: 0000-0002-2033-4660, Researcher ID Thomson: S7875-2018, CVU CONACYT ID: 386320

ID $1^{\text {st }}$ Coauthor: Rosa Elena Ochoa-Martínez / ORC ID: 0000-0002-0676-6387

ID $2^{\text {nd }}$ Coauthor: Evelyn Guadalupe, Torres-Capetillo / ORC ID: 0000-0003-0576-0327, Researcher ID Thomson: T1680-2018, CVU CONACYT ID: 308188

ID $3^{\text {rd }}$ Coauthor; Leticia Tiburcio-Morteo / ORC ID: 0000-0003-1806-4355

DOI: $10.35429 / E J B \cdot 2020.13 .7 .7 .10$

Received: July 16, 2020; Accepted: November 20, 2020

\begin{abstract}
Saliva is multifunctional: cleaning of the oral cavity, lubrication, preservation, repair of mucous membranes and dental hard tissues; the $\mathrm{pH}$ and its buffering, also participates in the elimination of bacteria, digestion and speech. The salivary composition in gestational period is altered, with variation of salivary $\mathrm{pH}$ and buffer capacity. Objective. To determine the levels of $\mathrm{pH}$ and salivary flow that prevail in pregnant patients. Methodology. Descriptive, prospective and transversal study. Sampling for convenience: pregnant patients in the 1st, 2nd and 3rd trimesters who attended the UMF. 61 to medical control of their pregnancy. Using a calibrated JENWAY $3510 \mathrm{Ph}$ Meter potentiometer. Saliva samples were collected at least one hour after eating. Contribution. The salivary $\mathrm{pH}$ in pregnant women is lower in the first quarter than in later ones. According to Spearman's test analysis, a positive correlation is reported $(\mathrm{r} 2=0.34)$, the correlation of ranges between $\mathrm{pH}$ and salivary volume is statistically significant even if it is weak. The salivary $\mathrm{pH}$ is lower in the first quarter than in the two subsequent ones, the salivary flow does not vary significantly in the first and second quarters, but it increases in the third quarter.
\end{abstract}

Saliva, Ph, Pregnant women

\section{Resumen}

La saliva es multifuncional: limpieza de cavidad bucal, lubricación, conservación, reparación de membranas mucosas y tejidos dentales duros; el $\mathrm{pH}$ y su amortiguación, también participa en la eliminación de bacterias, la digestión y el habla. La composición salival en periodo gestacional se ve alterada, con variación del pH salival y la capacidad buffer. Objetivo. Determinar los niveles de $\mathrm{pH}$ y flujo salival que prevalecen en las pacientes gestantes. Metodología. Estudio Descriptivo, prospectivo y transversal. Muestreo por conveniencia: pacientes gestantes $1^{\circ}, 2^{\circ}$ y 3 er trimestre que acudieron a UMF. 61 a control médico de su embarazo. Empleando un potenciómetro JENWAY 3510 Ph Meter, calibrado. Las muestras de saliva fueron recolectadas al menos una hora después de comer. Contribución. El pH salival en gestantes es menor en el primer trimestre que en los posteriores. De acuerdo con la prueba de análisis de Spearman, se reporta una correlación positiva $\left(r^{2}=0.34\right)$, es estadísticamente significativa la correlación de rangos entre el $\mathrm{pH}$ y el volumen salivales aun cuando es débil. $\mathrm{El} \mathrm{pH}$ salival es menor en el primer trimestre que en los dos posteriores, el flujo salival no varía significativamente en el primer y segundo trimestres, pero si aumenta en el tercer trimestre.

Saliva, Ph, Gestantes

Citation: CAPETILLO-HERNÁNDEZ, Guadalupe Rosalía, OCHOA-MARTÍNEZ, Rosa Elena, TORRES-CAPETILLO, Evelyn Guadalupe and TIBURCIO-MORTEO, Leticia. Salivary Flow and ph in pregnant patients. CORFAN JournalBolivia. 2020. 7-13: 7.10

\footnotetext{
* Correspondence to Author (email: gcapetillo@uv.mx)

$\uparrow$ Researcher contributing as first author
} 


\section{Introduction}

Saliva is a fluid present in the oral cavity made up of $99 \%$ water and a minimal amount of electrolytes, tiny organic molecules such as hormones and glucose, as well as proteins such as immunoglobulins, enzymes and glycoproteins whose quantity and quality they influence the ability of saliva to perform various functions throughout the day. It is a fluid that, in addition to being composed of the secretions of the major and minor salivary glands, contains a mixture of gingival exudate, microorganisms and their products, epithelial cells, nasal exudate and food remains. Hernández Molinar and Cols. 2019.

Pregnancy is a period of significant physiological, metabolic and morphological changes in women, which elapses from the implantation of the zygote in the uterus until the moment of delivery, with the function of nourishing and allowing the development of the fetus and preparing the body for the mother for breastfeeding. Gestation refers to the development of the fetus, many people refer to these two terms synonymously.

Specifically, changes will occur in the oral tissues produced by the modification of the $\mathrm{pH}$ level and the amount of salivary flow, these factors when affected produce favorable conditions for the development and the appearance of biofilm, giving rise to conditions that favor the presence of cavities and periodontal disease, affecting oral health. Bouza Vera et al. 2016.

Saliva is composed of water in about $99 \%$, while the remaining $1 \%$ is made up of inorganic compounds, proteins, carbohydrates, lipids, desquamated epithelial cells, bacteria and their products, viruses and fungi, food remains, some bronchial secretions and components of crevicular fluid such as blood cells and immunoglobulins. It is sterile in its place of origin, but when it comes into contact with the crevicular fluid, other foods, microorganisms and desquamated cells of the oral mucosa, it stops being sterile. Edgar WM. 2016.

\section{Objective}

Determine the $\mathrm{pH}$ and salivary flow levels that prevail in pregnant patients.

\section{Methodology}

Descriptive, prospective and cross-sectional study. Convenience sampling: 1st, 2nd and 3rd trimester pregnant patients who attended the UMF. 61 to medical control of your pregnancy. Saliva samples were collected at least one hour after eating.

The sample was made up of 40 pregnant patients from different trimesters of pregnancy, who attended the 61 Family Medical Unit. The total volume of saliva was calculated without taking into account the foam, with an adjustable $1 \mathrm{ml}$ pipet, using plastic tips. The salivary flow rate was calculated taking into account the total collection time and the volume of saliva.

A JENWAY $3510 \quad \mathrm{Ph}$ Meter potentiometer was used, which was previously calibrated by using two buffer substances, one with $\mathrm{pH} 5$ and the other with $\mathrm{pH} 9$. Once calibrated, each sample was measured using the electrode. By recording the results obtained in the registration table of pregnant patients who attended UMF No. 61 and who met the selection criteria, the $\mathrm{pH}$ value found was placed in the patient's collection form.

\section{Results}

Salivary $\mathrm{pH}$ in pregnant women is lower in the first trimester than in the later ones. According to the Spearman analysis test, a positive correlation is reported $(\mathrm{r} 2=0.34)$, the correlation of ranges between $\mathrm{pH}$ and salivary volume is statistically significant even when it is weak. Salivary $\mathrm{pH}$ is lower in the first trimester than in the subsequent two, salivary flow does not vary significantly in the first and second trimesters, but does increase in the third trimester.

\begin{tabular}{|l|l|l|l|l|}
\hline \multicolumn{5}{|l|}{ Gestational Trimester } \\
\hline $\begin{array}{l}\text { Gestational } \\
\text { Trimester }\end{array}$ & $\begin{array}{l}\text { 1st } \\
\text { Trimester }\end{array}$ & $\begin{array}{l}\text { 2nd } \\
\text { Trimester }\end{array}$ & $\begin{array}{l}\text { 3rd } \\
\text { Third }\end{array}$ & Total \\
\hline Px Pregnant & 5 & 15 & 20 & 40 \\
\hline & $12.50 \%$ & $37.50 \%$ & $50 \%$ & $100 \%$ \\
\hline n-\% & $5-12 \%$ & $\begin{array}{l}15-37.5 \\
\%\end{array}$ & $\begin{array}{l}20 \\
50 \%\end{array}$ & $\begin{array}{l}40 \\
100 \%\end{array}$ \\
\hline
\end{tabular}

Table 1 Pregnant patient population by gestational trimester 
Population of Pregnant Patients by age.

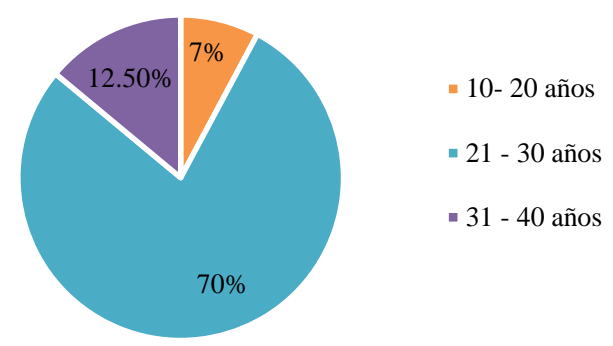

Graphic 1 Percentage population of pregnant patients by age

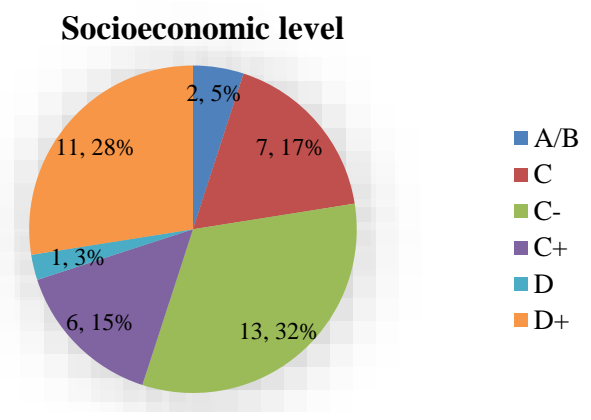

Graphic 2 Socioeconomic level of the pregnant women in the study

Of the total sample of 40 patients, who completed the socioeconomic questionnaire, we found that the socioeconomic level that most predominates in $\mathrm{C}$-, followed by $\mathrm{D}+$, the socioeconomic level that least predominates is D.

The classification in Mexico is:

- $\quad$ Socioeconomic Level A / B is High

- Socioeconomic Level C + is Medium High

- Socioeconomic Level C is Typical Medium

- Socioeconomic Level C- is Medium Emerging

- $\quad$ Socioeconomic Level D + is Low Typical

- Socioeconomic Level D is Extreme Low

- Socioeconomic Level E is Low Very Extreme

\begin{tabular}{|l|l|l|l|}
\hline \multicolumn{4}{|c|}{ Central trend measures in relation to the study variables } \\
\hline Pregnant & Trimester & Salivary volumen & PH \\
\hline Half & 2.37 & 6.39 & 7.6 \\
\hline Fashion & 3 & 6 & 7.3 \\
\hline Median & 2 & 6 & 7.6 \\
\hline
\end{tabular}

Table 2 Central trend
Spearman analysis

\begin{tabular}{|l|l|l|l|}
\hline $\begin{array}{c}\text { Independent } \\
\text { variables }\end{array}$ & \multicolumn{1}{c|}{$\begin{array}{c}\text { Standard } \\
\text { deviation }\end{array}$} & \multicolumn{1}{c|}{ Coefficient } & \multicolumn{1}{c|}{ P } \\
\hline Salivary pH & 0.34 & 0.34 & $\begin{array}{l}0.033 \\
*\end{array}$ \\
\hline Salivary volume & 3.77 & & \\
\hline
\end{tabular}

Table 3 A p of 0.05 was established as statistically significant

According to the Spearman analysis test, a positive correlation is reported $(\mathrm{r} 2=0.34)$, the correlation of ranges between $\mathrm{pH}$ and salivary volume is statistically significant even when it is weak.

\section{Discussion}

It has been shown that there are variations in the chemical composition of saliva and that this varies not only from subject to subject, but within the same subject. Numerous factors are those that influence both the quality of salivary flow and its composition, among which are: eating, circadian rhythm, sex, age, climate, height, as well as ingestion of drugs, drugs, genetic factors and physiological states.

In the present study of 40 pregnant patients, it was found that the salivary $\mathrm{pH}$ of pregnant women is lower in the first trimester than in the subsequent two, due to continuous nausea, vomiting, absence of toothbrushing, hormonal factors, as well as the time The collection of saliva and the stimulus used play a preponderant role in saliva $\mathrm{pH}$.

In the present study we were able to observe that salivary flow does not vary significantly in the first and second trimesters of pregnancy, but it does increase in the third trimester, according to the work of Hernández Molinar, 2019, giving as a possible explanation the hormonal factor, which plays an important role in saliva secretion.

\section{Conclusions}

- The research hypothesis is affirmed, concluding: There is a relationship between the $\mathrm{pH}$ level and the amount of salivary flow in pregnant patients.

The patients of the population that predominated the most during the study carried out were those in the third trimester. 
- According to the information collected from 40 patients, the average salivary $\mathrm{pH}$ was 7.6.

- According to the information collected from 40 patients, the average salivary volume was $6.3 \mathrm{ml}$.

- Finally, it is concluded according to Sperman's statistical study that there is a positive and significant correlation between the two study variables of $\mathrm{p}=$ 0.033

\section{Acknowledgments}

To the Universidad Veracruzana and the collaboration of the Academic Body UV-CA288 "Education, health and oral epidemiology", as well as the UMF 61.

\section{References}

Bouza Vera, Meylín, Martínez Abreu, Judit, Carmenate Rodríguez, Yamila, Betancourt González, Magdalena, \& García Nicieza, Maydelis. (2016). Pregnancy and oral health. Revista Médica Electrónica, 38(4), 628634.http://scielo.sld.cu/scielo.php?script=sci_ar ttext\&pid=S1684-

$18242016000400013 \& \operatorname{lng}=$ es\&tlng=en.

Cahuana, A., Palma, C., González, Y., \& Palacios, E. (2016). Salud bucodental maternoinfantil. ¿Podemos mejorarla? Matronas Profesion, 17(1), 12-19.

Chapa Arizpe MG. Diferencia en el flujo salival en pacientes con hipofunción de las glándulas salivales por medio de la aplicación de neuroelectro-estimulación. 2012 [cited 2017 Mar 25]; Available from: http://eprints.uanl.mx/2666/

Edgar WM. Saliva: its secretion, composition and functions. Br Dent J [Internet]. $1992 \mathrm{Apr}$ 25 [cited 2016 Oct 20];172(8):305-12. Available

from:http://www.ncbi.nlm.nih.gov/pubmed/159 1115

Hernández-Molinar, Y., Aranda-Romo, S., Dávila-Pérez, C. E., \& Goldaracena-Azuara, M. P. (2019). Probióticos como bacterioterapia para fortalecer capacidad buffer y disminuir la viscosidad de saliva en pacientes pediátricos, Facultad de Estomatología de la UASPL. Revista Oral, 20(64), 1750-1754.
Ismail, A. F., Ardini, Y. D., Mohamad, N., \& Bakar, H. A. (2018). Association between parental oral health literacy and children's oral health status. Revista Latinoamericana de Hipertension, 13(3), 305-309.

Martínez-Pabón, M. C., Martínez Delgado, C. M., López-Palacio, A. M., Patiño-Gómez, L. M., \& Arango-Pérez, E. A. (2014). Características fisicoquímicas y microbiológicas de la saliva durante y después del embarazo. Revista de Salud Pública, 16(1), $128-138$.

Patricia Escalante-Medina, R., Steven AsmatAbanto, A., \& Angel Ruiz-Barrueto, M. (2019). Efecto antibacteriano de una pasta dental con xilitol sobre Streptococcus mutans en saliva de gestantes. Revista Cubana de Estomatologia, 56(4), 1-12.

Quito DM De. Universidad central del Ecuador Facultad de Odontología “ Evaluación del pH salival en mujeres menopáusicas de 45 a 55 años de edad "Trabajo Teórico de Titulación Previo a la Obtención del Título de Odontóloga Simbaña Imba Johanna Pilar TUTORA : Dra . Mi. 2016;1:1-85 